\title{
Second Century: Cold Spring Harbor Laboratory and the Biotechnology Revolution
}

\begin{abstract}
In addition to its firmly established reputation as a leader in biological research and education, Cold Spring Harbor Laboratory has also occupied a prominent role in the biotechnology industry. Since 1980, the Laboratory has become intimately involved with commercial research, forming relationships and collaborative partnerships with major biotech leaders on Long Island and elsewhere. This paper will explore the transition of Cold Spring Harbor Laboratory (CSHL) from an institution dedicated solely to basic scientific research to one that was willing to take on a new role in for-profit biotechnology. This transition occurred at a time when academic institutions and commercial industries were in general moving closer together. This merging of interests, however, came not without concerns about corrupting the "pure" science of the academy. Such concerns were present at CSHL in the early 1980s, but they did not prevent the institution from making biotechnology - the application of the biological sciences to human problems - a part of its larger mission. By the 1990s, involvement in the industry had become a visible part of CSHL's research operations. Several of its scientists started their own companies, and the Laboratory, through its support for local start-up firms and business incubators, helped turn Long Island into a prominent center of biotechnology. Though CSHL's involvement with biotech continues, the events from the 1970s to the early 2000s constitute the Laboratory's formative initiation into the field. Since they are essential to understanding CSHL's current position in the biological sciences, these years are the focus of this narrative.
\end{abstract}

\section{Introduction}

Founded in 1890 by the Brooklyn Institute of Arts and Sciences, Cold Spring Harbor Laboratory (CSHL) was originally a training center for biology teachers known simply as "the Biological Laboratory.” The institution's early orientation toward both research and education remained a part of its mission, and since then, CSHL has stayed in the vanguard of science, with its last six decades in particular defined by its important work in molecular biology and genetics. As a research field, molecular biology grew out of the intense interest in understanding genetics at the chemical level. Classical genetics, the earlier iteration of the study of heredity, had treated genes as "black boxes": integral parts of inheritance whose inner workings were nevertheless a mystery. As knowledge and techniques improved, biology moved away from its descriptive origins toward probing the molecular mechanisms of life. CSHL-which then comprised the Biological Laboratory and the Department of Genetics of the Carnegie Institute of Washingtonsupplied many of the key people and ideas in this shift toward molecular genetics; still others were intimately linked with the institution. James Watson is perhaps the most famous, having cofounded the structure of DNA in 1953, a key pivot point in the molecular revolution. Watson had 
maintained close ties with CSHL both before and after his discovery and eventually became the Laboratory's director in 1968.

Just as biology itself had evolved, the nature of the institutions devoted to its study would undergo their own shift. As researchers realized the social utility of molecular biology, a push toward commercializing research took place, making the field became more competitive for patents and profits. While not a commercial research institution itself, CSHL nonetheless has positioned itself as a focal point of biotechnology. The modern biotechnology industry, an outgrowth of the discovery of recombinant DNA in 1973, has been heavily focused on the application of molecular genetics to treating human diseases. The goal has been to develop diagnostic tools, drugs, and other therapeutics as treatments for a variety of ailments, particularly genetic disorders such as cancer. Though the 1970s saw the rise of companies geared toward commercial research and development, there remained a sharp distinction between such companies and academic and other basic-research institutions. This distinction gradually blurred (though it hasn't completely disappeared) as it became more acceptable for the two types of institutions to collaborate.

CSHL's relationship with the biotechnology industry began in 1980, with the formation of Cellbiology Corporation, a for-profit company meant to serve as the Laboratory's "development arm.” Ever since, CSHL has maintained close ties with the industry, forging collaborations and research agreements with some of the most prominent biotechnology companies in the world: Exxon, Monsanto, and Genetics Institute are among the most notable. In addition, the Laboratory's scientists have established many of their own biotechnology companies. The story of CSHL's involvement with this industry is not without its rough spots, including the fears, particularly potent during the early 1980s, that business would corrupt the Laboratory's pristine reputation for good science. Like so many other institutions at that time, CSHL had to balance concerns about its reputation with the desire to move forward in science.

Though biotechnology at Cold Spring Harbor Laboratory began in earnest during the 1980s, the application of biological research to human issues had been a part of the Laboratory, to a limited extent, before then. Beginning in 1942, for instance, the Department of Genetics conducted government-sponsored research for the United States's efforts in the Second World War. Cooperating with the Chemical Warfare Service of the War Department, the Laboratory studied preventing the harmful effects of chemicals and bacteria on soldiers. This research included testing hypochlorite on airborne bacteria and conducting experiments with aerosols. The scientists also developed plastic nebulizers, both to disperse anti-microbial and anti-chemical aerosols into the air and to administer penicillin mist to infected patients. Another significant project at the time concerned penicillin. Then still considered a wonder drug, penicillin was in high demand during the war years as a treatment for soldiers' infections. In 1944, on contract with the federal Office of Scientific Research and Development, the Carnegie Institute 
completed a study on bacterial resistance to the drug. ${ }^{1}$ Milislav Demerec, who had signed on as the Carnegie Institute's director three years earlier, completed further work on penicillin; in particular, he was able to create high-yielding penicillium strains using X-rays. ${ }^{2}$

\section{Recombinant DNA and Academia's First Steps Toward Biotechnology}

If the era of modern biotechnology had to be fitted with a precise starting point, one could do worse than November 1973. That month, a paper appeared in the Proceedings of the National Academy of Sciences authored by Stanley Cohen, Herbert Boyer, Annie Chang, and Robert Helling. ${ }^{3}$ The paper described a method by which a recombinant plasmid could be constructed in vitro by joining two fragments of separate plasmids. What's more, after being inserted into $E$. coli, these recombinant plasmids could operate like fully functional replicons. Though other scientists-Paul Berg, for example-had worked on gene-splicing methods before the appearance of this particular paper, it was Cohen and Boyer who succeeded in getting the recombinant material to replicate inside the bacteria. Thus two decades after the double helix had revolutionized biology, the method of recombinant DNA was doing it all over again. The implications of the new technology were enormous. If, so the thinking went, the DNA molecule could be altered and manipulated at will, it stood to reason that genetic disorders could be treated, or even cured, by the proper kinds of alterations. Faulty or missing genes could be replaced (in theory) by functioning copies, for instance. This was the hope that recombinant DNA inspired among researchers; it served as the premise for a new industry based on using the technology to treat human disease.

Some of the basic tools of recombinant DNA are restriction enzymes, endonucleases that can cut the DNA molecule at specific points known as restriction sites. (The fragments are re-joined using DNA ligase.) In the early 1970s, the newly discovered enzymes were critical to making headway in recombinant DNA research; consequently, the demand for them soared. Cold Spring Harbor Laboratory figures into this history in an interesting way. Richard Roberts, an organic chemist, molecular geneticist, and future Nobel laureate, had come to CSHL in September 1972, and had become motivated to study restriction enzymes because of the possibility that they could be used to sequence DNA. This, Roberts has said, was the "sole reason I became interested in restriction enzymes." 4 At the time, while there were ways to sequence RNA, no methods existed to sequence DNA, since scientists did not have smaller DNA molecules on which to practice. ${ }^{5}$

\footnotetext{
${ }^{1}$ Long Island Biological Association, Annual Report of the Biological Laboratory, 1944, 14.

${ }^{2}$ Milislav Demerec, Annual Report of the Director of the Department of Genetics, Carnegie Institution of Washington Year Book No. 44, 1944-1945 [issued 1945], 103-108.

${ }^{3}$ Cohen, S.N., Chang, A.C.Y., Boyer, H.W., Helling, R.B., "Construction of Biologically Functional Bacterial Plasmids In-Vitro," Proceedings of the National Academy of Sciences of the United States of America 70, 1 November 1973: 3240-3244.

${ }^{4}$ Rich Roberts, phone interview with Robert Wargas and Mila Pollock, 12 April 2013.

${ }^{5}$ Ibid.
} 
Seeking to rectify this, Roberts began to use the new technology of agarose slab-gel electrophoresis to isolate more restriction enzymes. ${ }^{6}$ He kept finding more of them, and soon his lab became the only one to have a complete set of all known restriction enzymes. Wishing to work with these new finds, researchers from all over began to bombard Roberts's lab with requests for specific enzymes.

It wasn't long, therefore, before Roberts's lab became the leading center for restriction-enzyme production, with Roberts and his highly skilled technician, Phyllis Meyers, producing large amounts for scientists across the United States. ${ }^{7}$ Roberts also produced enzymes for labs overseas, including the Medical Research Council in Cambridge, U.K. ${ }^{8}$ As the demand rose, Roberts saw an opportunity both to make money for CSHL research and to lighten his own lab’s workload. In 1974, he approached James Watson and proposed that CSHL begin charging for the production of the enzymes. Essentially, it was a proposal to start a for-profit business (at a separate lab, off the grounds of CSHL) that would funnel revenues from restriction enzyme production and distribution into CSHL research. ${ }^{9}$

Watson declined, believing at the time that academic institutions as a whole (though not necessarily individual scientists) should avoid involvement with business ventures. ${ }^{10}$ Watson, in retrospect, has said that his decision was a mistake. ${ }^{11}$ Roberts's proposal came at a time when there was still a serious moral and philosophical barrier between centers of "pure" research like CSHL and commercial companies established to make a profit from developing and marketing biotechnology. It was not yet considered totally acceptable for the academy to engage in commercially oriented research, or even to collaborate with commercial companies on research projects. During the 1970s, however, a process began by which this barrier would eventually fade into insignificance.

\section{The Changing Face of Academic-Corporate Relationships}

One reason for this was the advent of the cooperative research grant: the funding of research projects by corporations. Before then, although it had been common for academic institutions to receive corporate money for their scientific research-Cold Spring Harbor, for instance, had

\footnotetext{
${ }^{6}$ Richard J. Roberts, "How restriction enzymes became the workhorses of molecular biology," Proceedings of the National Academy of Sciences 102, no. 17 (26 April 2005), 5907.

${ }^{7}$ Jim Hicks, Morgan Browne, Bill Keen, and John Maroney, interview with Robert Wargas \& Mila Pollock, Cold Spring Harbor Laboratory, 11 January 2013; Rich Roberts interview, 12 April 2013.

8 "How restriction enzymes became the workhorses of molecular biology," 5907.

${ }^{9}$ Rich Roberts interview, 12 April 2013.

${ }^{10}$ Ibid.

${ }^{11}$ James Watson, interview with Robert Wargas \& Mila Pollock, Cold Spring Harbor Laboratory, 13 May 2013.
} 
received grants from companies like I.B.M., Merck, and Pfizer in the $1970 \mathrm{~s}^{12}$ — the funds took the form of general, undirected contributions. These new grants were revolutionary in as much as they were corporate funds given to specific researchers for specific projects. The first such grant, according to one scholar, came in 1974, when Monsanto agreed to give Harvard Medical School \$23 million over a twelve-year period for cancer research in the lab of Judah Folkman. An arrangement of that nature and magnitude was unheard of at the time; the renowned journal Science noted that it was "an agreement that's unprecedented in the annals of academic business affairs." 13

The rest of the 1970s were a transformative period. In 1976, Genentech, the first major geneticengineering company, was established. It would eventually earn a stellar reputation for its scientists' role in creating synthetic human insulin, despite the skepticism many academics harbored toward market-oriented research. "In 1977 most professors, especially those in biology, still had grave doubts regarding the propriety of commercial ties,” wrote Martin Kenney, who completed an early but comprehensive study of academic-industrial relations in biotechnology, in 1986. These academic scientists “were reluctant to join companies because of peer pressure.” Those who did join, moreover, were viewed by their peers with a certain amount of disdain. ${ }^{14}$ Jim Hicks remembers that in the 1970s and early 1980s, there was a professional stigma attached to full-time research with a commercial company; industry scientists had reputations, whether deserved or undeserved, as being less competent than academics. "Anybody who was any good in cutting-edge [research] never went to work for a pharmaceutical company in those days,” Hicks said in an interview. John Maroney, who for over four decades has been involved in technology issues at CSHL, agreed, saying such a career move was viewed as a "demotion.”"15

Such a negative outlook constituted a genuine obstacle to opening a thriving business, since, according to Kenney, "in the late 1970s the formation of a genetic engineering company nearly always involved an entrepreneur soliciting various professors until he discovered one who was interested in forming a company." 16 This did not stop chemical and pharmaceutical companies, two pillars of industry, from recognizing, and seizing on, opportunities to expand into biotechnology. Before then, chemical companies like DuPont and Monsanto had remained entirely separate in their mission from pharmaceutical companies like Merck. With the discovery of genetic engineering, a potentially lucrative new business niche induced chemical companies to shift their traditional focus to smaller molecules. ${ }^{17}$

\footnotetext{
${ }^{12}$ See CSHL Archives, James D. Watson Collection (hereafter "Watson Collection”), 3/7/3, box 2.

${ }^{13}$ Martin Kenney, Biotechnology: The University-Industrial Complex (New Haven: Yale University Press, 1986), 58.

${ }^{14}$ Ibid., 96, 100.

${ }^{15}$ Jim Hicks et. al. interview, 11 January 2013.

${ }^{16}$ Kenney, 136-137.

${ }^{17}$ Ibid., 191.
} 


\section{A Shift in the Zeitgeist for CSHL}

For the rest of the decade, however, CSHL as an institution remained largely removed from the blooming new world of commercial science. This did not mean that certain individual scientists stayed away completely. After failing to win over James Watson with his idea to market restriction enzymes, Rich Roberts began to collaborate with Don Comb, an entrepreneur who had started a company called New England Biolabs in Cambridge, Massachusetts. Comb was interested in selling restriction enzymes, and Roberts agreed to be his company's chief consultant. After signing on with Comb, Roberts said that he and Watson no longer spoke about. ${ }^{18}$ Watson, in retrospect, said he didn't mind that Roberts was involved with an outside company; he saw no point in trying to stop him. ${ }^{19}$

It wasn't until 1980 that CSHL got serious about biotechnology. In January of that year, Watson reported to the Laboratory's Executive Committee that different venture-capital companies had approached the institution proposing to develop some of the CSHL's research. The Executive Committee vigorously discussed such proposals but failed to reach a consensus. ${ }^{20}$ This, according to the extant documentary record, appears to be one of the earliest mentions of commercially oriented research among CSHL administrators. This record is unclear about exactly when Watson and others at CSHL decided to consider biotechnology as a new route for the Laboratory, or why and when their views toward the industry evolved. Watson's views in particular are interesting for their apparent ambivalence, at least around 1980. In one respect, he was willing to consider some form of relationship with industry; in another respect, he was, owing to the unprecedented nature of such relationships at Cold Spring Harbor, cautious about proceeding.

Nevertheless, there were several reasons for the desire to move closer to the commercial world, and the fact that some of these reasons were out of administrators' hands may explain the conflicting views. For instance, as several CSHL alumni have acknowledged, there was a pressure to keep up with trends. As mentioned above, a discernible shift had taken place in the biological sciences, the effect of which was to narrow the gap between basic and applied research. In order for CSHL to maintain its leadership position in molecular biology, then, a certain acquiescence to this trend was necessary. There was also a lingering anxiety over revenue. Throughout the 1970s, the Lab had relied on the Cancer Center grant, the result of its designation as one of a few prestigious designated cancer centers in the United States, as an important funding source. CSHL had received the first five-year Cancer Research Center grant from the National Cancer Institute in January 1972. The resulting research had focused on using

\footnotetext{
${ }^{18}$ Rich Roberts interview, 12 April 2013.

${ }^{19}$ James Watson interview, 13 May 2013.

${ }^{20}$ Executive Committee Meeting, 22 February 1980, CSHL Archives, Norton Zinder Collection (hereafter “Zinder Collection”), box 130.
} 
tumor viruses (e.g. adenovirus, polyoma, and SV40) to study mammalian cell transformation. According to Guenter Albrecht-Buehler, a CSHL staff scientist from 1974 to $1982,{ }^{21}$ sometime near the end of the 1970s, the NIH attempted to push the Lab away from the focus on the genetics of cell transformation and toward a focus on cell biology. ${ }^{22}$

The pressure from the NIH meant that Watson, in Buehler's view, "had to consider shifting the focus of the Lab to cell biology, and it was obvious to me that he felt extremely uncomfortable about it." Watson was explicit about his reluctance to do this, since a shift in focus would mean a move away from what Buehler said were the more "profound visions" of molecular genetics. Buehler recalls conversations with Watson in which these concerns were explicit. "Still, in view of the pressure of the NIH," Buehler said, "something had to be done in order to secure the future funding, and among others, commercialization of the Lab's research offered itself to Jim as a possible source of future funding.”23

William Udry, who was the Administrative Director of the Laboratory from 1971 to 1984, has agreed that although CSHL had overcome the dire financial situation it had faced in the 1960s and early 1970s, it was still in "somewhat poor shape financially" in the late 1970s and early 1980s. Despite the financial cushion provided by the Robertson Research Fund, established in 1973, the Laboratory still needed other sources of revenue. "We were always interested in money," Udry said. "I got involved pretty early in talking to businesses.” Though businessoriented research in general seemed inevitable, the exact nature of that new path remained unclear. A relevant question was what CSHL should do about potentially profitable research results coming out of its laboratories. ${ }^{24}$ Should they market them? Should they collaborate with other companies? Should they seek to open a for-profit biotechnology company, as scientists like Walter Gilbert and Herbert Boyer had done? ${ }^{25}$

These questions coincided with the conflict still raging in molecular biology over whether the profit motive was an honorable one for a university to pursue. In some cases biotechnology ended up a casualty of academic skepticism. In 1980, for example, Harvard tried to start its own genetic-engineering company. Similar to what CSHL would end up proposing, Harvard administrators envisioned a university-affiliated company that would market Harvard professors' research. The idea backfired. There was a tremendous negative reaction to the concept of a university-industry nexus. In fact, the entirety of Cambridge civil society seemed to rebel against it; reactions came from Harvard faculty, the media, and the surrounding community. ${ }^{26}$ The

\footnotetext{
${ }^{21}$ http://www.basic.northwestern.edu/g-buehler/cv.htm. Accessed 15 May 2013.

${ }_{22}$ Guenter Albrecht-Buehler, email to Robert Wargas, 9 November 2012.

${ }^{23}$ Ibid.

${ }^{24}$ William Udry, phone interview with Robert Wargas, 4 December 2012.

${ }^{25}$ Bayard Clarkson, a former trustee, agreed that the Lab was still financially unsure of itself circa 1980, and that biotech offered itself as a possible solution to this. Bayard Clarkson, phone interview with Robert Wargas, 28 November 2012.

${ }^{26}$ Kenney, Biotechnology, 78-79.
} 
controversy was not contained to Massachusetts. One morning-October 27, 1980_Derek Bok, the president of Harvard, woke to see his face on the front page of the New York Times. The report concerned the university's proposed genetic-engineering company. "During the weeks that followed," Bok wrote two years later, reflecting on the incident, “articles appeared in dozens of newspapers and magazines debating the merits and demerits of entering into commercial ventures of this kind. Scientists and editorial writers quickly volunteered their own opinions, most of them hostile."27

By the middle of 1980, Watson and CSHL administrators were in the middle of their own negotiations regarding a proposed British company called Celltech. Originally intended to be a collaboration between CSHL, the Medical Research Council Laboratory of the University of Cambridge, and the Imperial Cancer Research Fund, it was set up with capital from the U.K. National Enterprise Board, among other sources. ${ }^{28}$ CSHL was serious about joining. In June 1980 Watson and other administrators headed to England to meet with those involved in the venture. ${ }^{29}$ Ultimately, though, Watson decided not to go ahead with the collaboration; the idea was, in his words at the time, to "go it alone and form our own company," which CSHL administrators had already been discussing since the beginning of $1980 .{ }^{30}$ This solo idea was Cellbiology Corporation, which was envisioned as the Laboratory's own for-profit biotechnology company.

After nearly a year of discussion among the trustees, Cellbiology was incorporated in November $1980 .{ }^{31}$ At the end of the 1981 annual report, Watson announced that the company had been created "to help respond to any such [commercial] opportunities if they arise...."32 The decision was an important one and was not without its detractors. These were still the early days of the academic-commercial crossover; certain scientists and trustees worried that business relationships would only erode the integrity and quality of science. They worried, for instance, that researchers would become too concerned with profits, and that a culture of secrecy would develop among researchers collaborating with different corporations. Despite these difficult questions and the skepticism that surrounded them, the legal and political climates in 1980 were shifting in biotechnology's favor. Two developments in particular stand out above the rest. The first was a United States Supreme Court decision of June 16, 1980, in the case of Diamond v.

\footnotetext{
27 “Harvard Considers Commercial Role in DNA Research,” New York Times, 27 October 1980, A1; Derek Bok, Beyond the Ivory Tower: Social Responsibilities of the Modern University (Cambridge, Mass.: Harvard University Press, 1982), 136.

28 "One way ahead for British biotechnology,” Nature, vol. 285, 5 June 1980; "British biotechnology boat comes home,” Nature, vol. 286, 24 July 1980.

${ }^{29}$ Memorandum, William Udry to Committee on Commercial Relations of the Laboratory, 9 June 1980, Zinder Collection, box 130.

${ }^{30}$ James Watson to G.H. Fairtlough, 17 September 1980, Zinder Collection, box 130.

${ }^{31}$ Certificate of Incorporation of Cellbiology Corporation, 20 November 1980, Cellbiology Corporation document binder, CSHL Archives.

${ }^{32}$ CSHL Annual Report 1981, 16. It should be noted that although Cellbiology was created in 1980, it essentially lay dormant for a while before business began.
} 
Chakrabarty. ${ }^{33}$ The case concerned a microbiologist named Ananda Chakrabarty, who while working for General Electric had engineered a bacterium that could ameliorate oil spills by breaking down the crude oil itself. In 1972, Chakrabarty had filed a patent application for the invention that included the process for making the bacterium as well as the engineered organism itself. The U.S. Patent and Trademark Office denied the patent, arguing that living organisms could not be patented according to U.S. law.

The case made its way to the U.S. Supreme Court, which ruled, in a five-to-four decision on June 16,1980 , that "anything under the sun that is made by man" is eligible for a patent. ${ }^{34}$ The landmark decision came under some significant criticism. Harold J. Morowitz, the renowned biophysicist, wrote in the New York Times that the "radical" decision was "simple reductionism" that refused "to draw a sharp distinction between animate and inanimate matter." He referred to this as "reducing life to physics." ${ }^{35}$ Another group, calling itself the "People’s Business Commission," invoked dystopian literature and wrote that "the Brave New World that Aldous Huxley warned of is now here." ${ }^{36}$

In reality, the decision was part of the same cultural shift in which Cold Spring Harbor Laboratory and other institutions found themselves. Governments-local, state, and federalwere responding to the demands and requirements of a new industry. In December 1980, the U.S. Congress passed the Bayh-Dole Act, which created a uniform patent policy for all federal agencies that fund research. The legislation also allowed universities and non-profit research institutions that received federal funding to own the inventions arising from their funded research. (Previously, the U.S. government took title to all such inventions.) These two decisions made the field of biotechnology even more attractive for academic institutions, including CSHL; not wishing to be left behind, the Lab positioned itself to assume a prominent role. ${ }^{37}$

\section{Cellbiology Corporation and CSHL's Transition into Biotechnology}

It is not entirely clear from the documentary record who came up with the idea for Cellbiology. Sambrook, in a 2013 interview, was confident that it was Watson's idea. Ironically, both Watson and John Maroney, who had worked closely with Udry and became the Lab’s assistant administrative director in 1982, had guessed that it was Joe Sambrook's initiative. ${ }^{38}$ Sambrook

\footnotetext{
${ }^{33}$ Diamond v. Chakrabarty, 447 U.S. 303 (1980).

${ }^{34}$ Douglas Robinson and Nina Medlock, "Diamond v. Chakrabarty: A Retrospective on 25 Years of Biotech Patents,” Intellectual Property \& Technology Law Journal 17, no. 10 (October 2005), 12.

${ }^{35}$ Harold J. Morowitz, "Reducing Life to Physics,” New York Times, 23 June 1980.

36 "Science May Patent New Forms of Life, Justices Rule, 5 to 4,” New York Times, 17 June 1980.

${ }^{37}$ John Maroney interview, 28 September 2012.

${ }^{38}$ James Watson, interview by Robert Wargas \& Mila Pollock, Cold Spring Harbor Laboratory, 13 May 2013; John Maroney interview, 28 September 2012.
} 
denied this, saying that he, like many others, wasn't “terribly keen about it." ${ }^{39}$ Hired to study tumor viruses, Sambrook became a leading figure at the Laboratory, assuming the positions of Assistant Director from 1977 to 1985 and Acting Director from mid-1983 to mid-1984, the latter position filled while Watson was on sabbatical. Both men maintained a close working relationship, talking "all the time," according to Watson; he credits Sambrook as a motivating force at the Laboratory. ${ }^{40}$

William Udry kept an extensive journal record of his time at CSHL. He noted that, at a private meeting on February 12, 1980, Watson wanted CSHL's commercial activities restricted to monoclonal antibodies. Though the Laboratory would soon embrace the idea of establishing its own for-profit biotechnology company, Watson harbored negative feelings toward such a move. Udry's journals, for example, reveal that Watson thought involvement with technology companies "would ruin the Lab” despite their profitability. ${ }^{41}$ Joe Sambrook, however, recalled that when it came to commercialization, Watson was "for it." ${ }^{42}$ It is unclear how, why, or when Watson's views evolved-although he has maintained, as of 2013, that he was always supportive of commercialization, saying he wanted to see science "incentivized" at CSHL. ${ }^{43}$ Sambrook, however, remembers that it was "a very difficult time for all of us," that "we all had reservations" about establishing a business: the prospect of having "mixed financial arrangements"- that is, the inherent conflict of simultaneously running a non-profit and forprofit enterprise—-worried Sambrook and others. ${ }^{44}$

The same concerns that had foreclosed on Harvard's plan for a biotech company seeped into the discussion at Cold Spring Harbor. The more traditional academic scientists viewed themselves as having the "pure" motive of understanding the nature of life, not the profit motive of entrepreneurs. The highest priority for Trustees and scientists, whatever their opinion on biotechnology, was preserving CSHL's academic integrity. In 1980, during the planning stages for Cellbiology Corporation, Lab administrators felt that there were three general ways in which CSHL could initiate itself into the commercial world: (1) an outside company could fund the Lab's research via grants or contracts; (2) the Lab's licensing its research results to a company in exchange for royalties; and (3) the Lab becoming involved in actually running or helping to run a commercial entity. Dr. Harry Eagle, a trustee, noted that the first two options were relatively non-controversial; the third, however, was the one that was most likely to generate controversy. ${ }^{45}$

\footnotetext{
${ }^{39}$ Joe Sambrook and Mary-Jane Gething, phone interview with Robert Wargas \& Mila Pollock, 14 June 2013.

${ }^{40}$ James Watson interview, 13 May 2013.

${ }^{41}$ William Udry, phone interview with Robert Wargas, 4 December 2012. It's important to note that the quote from Udry's diary was his own recollection of what Watson said.

42 Joe Sambrook (with Mary-Jane Gething), phone interview with Robert Wargas \& Mila Pollock, 14 June 2013.

43 James Watson interview, 13 May 2013.

${ }^{44}$ Joe Sambrook and Mary-Jane Gething interview, 14 June 2013.

${ }^{45}$ Executive Committee Meeting, 18 April 1980, Zinder Collection, box 130.
} 
Still, it was the third option that the Lab chose. Cellbiology was planned as the for-profit "arm" of Cold Spring Harbor Laboratory, a developmental clearinghouse, as it were, through which the staff's potentially lucrative research results could be developed and marketed. ${ }^{46}$ The Lab was not merely seeking commercial grants; it was seeking to open a bona fide business. This upset certain people. The Board of Trustees met on April 19, 1980, and discussed business possibilities at length. Their caution was reflected in the minutes of that meeting. For example, "several scientists/trustees pointed out that once a retainer-like relationship was established with industry, it was an irrevocable step and would in the natural course of events lead to some direction for a scientist to look for things of interest to the outside corporation." 47

Such attitudes were common at the time, at CSHL and elsewhere. The fear was that corporations would begin to exert influence and pressure on the research institutions with which they collaborated; moreover, as different scientists at the same institution picked up contracts from competing corporations, an atmosphere of secrecy could develop that would impede collaboration among researchers. Whereas a relatively open culture among scientists had existed previously, administrators feared an irrevocable shift would take place that would destroy the friendly atmosphere in which good science had taken place.

\section{Tissue Plasminogen Activator}

Cellbiology's first (and, it turns out, only ${ }^{48}$ ) major project concerned developing a recombinant form of tissue plasminogen activator (TPA), a protein that aids in dissolving blood clots. According to Angus McIntyre, Cellbiology's responsibilities included the identification of the TPA gene sequence clones, the expression of that gene in E. coli to synthesize a large yield of TPA, the isolation of the synthesized molecules, and the creation of a purification system. ${ }^{49}$ Working with Baxter Travenol Laboratories, ${ }^{50}$ Cellbiology recruited several scientists to work on the project, including Mary-Jane Gething, a protein chemist from the UK. Cellbiology also partnered with Genetics Institute, which was then a relatively new company in Cambridge, Massachusetts. It turned out that Cellbiology would have to compete with Genentech. Since

\footnotetext{
${ }^{46}$ Outline of Protocol, 13 October 1981, CSHL Archives, Office of Technology Transfer files, boxes 1 and 2. This document proclaims CSHL's “intention...to make Cellbiology Corp. its commercial arm.” Part of this plan involved Cellbiology's paying CSHL five percent of its gross income, though it is unclear whether this percentage was adhered to.

${ }^{47}$ Minutes of the 50th Meeting of the Board of Trustees, 19 April 1980, Zinder Collection, box 130.

${ }^{48}$ Cellbiology had planned to make the marketing of monoclonal antibodies a central part of its business, but while CSHL itself did get involved with monoclonals, it doesn't appear to have been through Cellbiology. Also, Cellbiology did complete a study for Southern Pacific Petroleum on "the use of microorganisms to aid in extracting oil from oil shale.” See Ian McFarlane to Angus McIntyre, 15 September 1981, CSHL Archives, Office of Technology Transfer files, boxes 1 and 2. See also "Manufacturing Requirements," undated [circa 1981], ibid.

${ }^{49}$ Angus McIntyre to Vernon Loucks, 3 June 1991, ibid.

${ }^{50}$ See, for example, Angus McIntyre to Vernon Loucks, 3 June 1981, ibid.
} 
early on in the project, there had been rumors that Genentech had already found a clone for TPA. Joe Sambrook reminded everyone that finding a clone was only one step in a long, complex process of development and marketing. Moreover, Angus McIntyre anticipated that Cellbiology and Genentech would end up using different processes to produce TPA-which would mean separate patents. $^{51}$

The idea to work on TPA grew out of meetings Jim Watson had attended in Japan for the Asian Molecular Biology Organization (AMBO) around $1980 .^{52}$ According to Sambrook, Watson came back to CSHL excited about the possibilities of developing urokinase, an enzyme produced by the kidneys (and found in urine) that can aid in dissolving blood clots. ${ }^{53}$ After Dan Rifkin of New York University, however, suggested that TPA was a better protein, a friend of Watson's named Roger Sammit put Watson in contact with Vernon Loucks, the CEO of Baxter Travenol. Sammit was crucial in arranging the initial meeting, which developed into a business relationship when Watson was able to sell the idea of developing TPA for the drug market. ${ }^{54}$

Unfortunately, the news of Genentech's successful cloning of TPA was out by the summer of 1982. Though it would take Cellbiology scientists another several months to get their own clone, Loucks hoped that Baxter Travenol would be able to "beat them [Genentech] to the marketplace." 55 Mary-Jane Gething recalls that "we were obviously disappointed, but the fact is we weren’t surprised.” Genentech had been working feverishly on TPA. (Susan Bonitz, a biologist who would later come to CSHL as part of its collaboration Exxon, recalls that, as a post-doc at Genentech, she could see Dave Goeddel working on TPA constantly in his office down the hall. ${ }^{56}$ ) Gething attributes Genentech's triumph to the fact that they had more full-time scientists working on it. Some friction and competition with Genetics Institute may have also slowed Cellbiology's work down. ${ }^{57}$

In the summer of 1984, Baxter sold its interests in TPA to Burroughs Welcome. By that time (as early as 1982, in fact) CSHL administrators had already considered shutting down Cellbiology, as the TPA project was the only job it was working on. Though the company was not officially dissolved until 1995, ${ }^{58}$ Cellbiology lay dormant after its work on TPA had been completed. Cellbiology's short life-span has been attributed to several things. John Maroney believes the company was inherently flawed from a business standpoint: "clearinghouse"-type companies, in which an academic institution funnels marketable research through a biotechnology "arm," have

\footnotetext{
${ }^{51}$ Angus McIntyre to Raymond Oddi, 21 December 1981, CSHL Archives, ibid.

${ }^{52}$ Watson's travel records show that he went to Japan in 1980 and 1981 for, respectively, the first meeting of AMBO's organizing committee and the AMBO Symposium. See Watson Collection, 2/14, box 2.

${ }^{53}$ Mary-Jane Gething \& Joe Sambrook interview, 14 June 2013.

${ }^{54}$ Ibid.

${ }^{55}$ Vernon Loucks to James Watson, 3 August 1982, CSHL Archives, Office of Technology Transfer files, boxes 1 and 2.

${ }^{56}$ Susan Bonitz, phone interview with Robert Wargas, 30 November 2012.

${ }^{57}$ Mary-Jane Gething \& Joe Sambrook interview, 14 June 2013.

${ }^{58}$ Cellbiology Corporation document binder, CSHL Archives.
} 
not done well in the past. Jim Hicks agreed, saying such companies try "to serve too many masters." ${ }^{59}$ Financial problems, especially with capitalization, inevitably follow. Sambrook has said that Cellbiology was "destined to fail” because a proper funding scheme was never worked out. He also believes that the failure to secure a separate laboratory building for research—CSHL had entertained purchasing an empty school building for Cellbiology, but the deal was never completed-helped doom the corporation.

\section{The Exxon Deal: A Watershed Moment in Commercial Collaboration}

Despite Cellbiology's failure to become a long-term concern, CSHL stayed committed to new commercial ties. The next milestone came in 1982: a collaboration with the Exxon Research and Engineering Company. Sensing the trends at the time, Exxon had thought it a good idea to move in the direction of molecular biology and biotechnology. Their plan was to contribute funding to CSHL's research in exchange for the training of Exxon scientists in biological techniques, specifically recombinant DNA. For CSHL, the Exxon deal represented the first major injection of corporate money into the Laboratory; it was also the first time the Lab undertook training scientists from a commercial company. (For these reasons the deal was mildly controversial.) Exxon's interest in CSHL had been spurred by the former's interest in the genetic engineering of enzymes.

While Exxon had engaged in microbiological research, it had yet to develop advanced capacity in molecular biology; the collaboration was thus Exxon's attempt to initiate itself into that field. Exxon even had a \$750-million research facility in New Jersey in the works for this new research direction. ${ }^{60}$ The collaboration program called for CSHL to train six carefully selected Exxon scientists in the methods of genetic engineering. By the end of 1982, Susan Bonitz and Steve Hinton, two Exxon scientists, had begun research at CSHL. The Lab had also recruited several new staff members of its own who would work with the Exxon scientists, including Mark Zoller for site-specific mutagenesis and Fevzi Daldal for anaerobic genetics. ${ }^{61}$ Though it is unclear who initially approached whom with the idea for this collaboration, Watson coordinated with Edward David, who was then president of Exxon Research and Engineering; the specifics of the deal were negotiated by William Udry, whom several senior people at CSHL have given credit for the final agreement. ${ }^{62}$

\footnotetext{
${ }^{59}$ Jim Hicks et. al. interview, 11 January 2013.

${ }^{60}$ Board of Trustees Meeting, 16 January 1982, CSHL Archives, Minutes 1980-1982; Draft, Outline of Agreement between CSHL and Exxon, 5 January 1982, Zinder Collection, box 131; Harbor Transcript, vol. 1, no. 1, May 1983.

61 “Academic Marriages of Convenience,” Newsday, 7 July 1982; Harbor Transcript, vol. 1, no. 1, May 1983.

${ }^{62}$ James Watson, interview by Robert Wargas \& Mila Pollock, Cold Spring Harbor Laboratory, 13 May 2013. John Maroney agrees that Udry was the point man for the negotiations.
} 
The collaboration was indeed a fruitful one for CSHL, which was able to secure ample funding in exchange for little overhead or obligation. For James Watson, the deal grew out of "the imperative to radically expand our facilities for protein chemistry at the micro level.... But we saw no immediate way to obtain the funds to add the new space to Demerec, our laboratory best suited for such work." 63 Underlying the Exxon deal, however, was the same trepidation that had found its way into the debate over Cellbiology. There was still discomfort over how increasing involvement in biotechnology might adversely affect the Laboratory. Since CSHL hadn't yet undertaken a major collaborative project with a commercial entity, some administrators urged that the Lab take a more conservative approach; they were, for instance, apprehensive that such a project would fundamentally change the nature of the Lab.

An outspoken skeptic of CSHL's new industry-oriented approach in general, and of the Exxon deal in particular, was Norton Zinder, a renowned scientist and trustee. In an Executive Committee Meeting in February 1982, Zinder worried that the Lab was becoming too cozy with the commercial aspects of biotech and warned that the agreement with Exxon-indeed, any agreement with a business-would drastically change the way the Lab operated. He even put forward the view that good science was completely incompatible with the goals and methods of a corporation. ${ }^{64}$ Susan Bonitz, the Exxon scientist who worked in the Delbruck Laboratory, ${ }^{65}$ remembers that "there were a lot of people who were pretty suspicious about getting this collaboration started," mainly because Exxon was a large corporation (and an oil company to boot), which some at CSHL still regarded as a corrupting force. Nevertheless, Bonitz also remembers a noticeable excitement from others at the Laboratory who were interested in seeing the deal work. ${ }^{66}$

The Exxon collaboration, unfortunately, did not lead to any research milestones for either institution. In fact, things ended prematurely: Bonitz has said that her work in mitochondrial DNA was cut short when she was informed by Watson, sometime around 1984 or so, that her time at CSHL was ending. ${ }^{67}$ Watson, speaking in a 2013 interview, said that Exxon had depended on stable oil prices to help finance their entry into molecular biology, and when the price of oil dropped significantly in the early and mid-1980s, ${ }^{68}$ their plans to move forward were stymied. ${ }^{69}$ Though Exxon's research presence at CSHL eventually dwindled, they met their contractual obligations to fund CSHL, and this money was enough for CSHL to help finance its

\footnotetext{
${ }^{63}$ CSHL Annual Report 1982, 7.

${ }^{64}$ Executive Committee Meeting, 20 February 1982, Minutes 1980-1982.

${ }^{65}$ The building was then known as the Davenport Laboratory.

${ }^{66}$ Susan Bonitz, phone interview by Robert Wargas, 29 November 2012.

${ }^{67}$ Ibid.

${ }^{68}$ Energy crises in the 1970s had pushed the price of oil to historic highs; after 1980, the price of oil continued to drop throughout the decade.

${ }^{69}$ James Watson interview, 13 May 2013.
} 
own expansion. This included an addition to Demerec Laboratory. Watson has also said that the Exxon money was necessary for CSHL to fund research in plant genetics as well. ${ }^{70}$

\section{CSHL Scientists Become More Involved in Biotechnology}

Cold Spring Harbor's relationship with biotechnology has included not just collaboration with outside corporations but the entrepreneurship of its own scientists in establishing their own companies. The first such company, Protein Databases Inc. (PDI), officially began business operations in 1984, although the planning and start-up of the company went back several years. PDI was based on work in 2D gel electrophoresis by two scientists, Robert Franza and Jim Garrels. Franza came to CSHL in July 1982 for the specific reason of working with Garrels. He and Garrels had discussed the potential marketing of the latter's work in 2D gel technology. ${ }^{71}$ The goal was not so much to make money as to ensure that the technology was widely available to other researchers. ${ }^{72}$ In July 1983, the two scientists began to look for venture capital. One company that expressed interest was the major Manhattan firm Alan Patricof Associates, Inc. ${ }^{73}$ Franza, a year earlier, had been introduced to Alan Patricof, who then introduced Franza to Alan Schwartz of Bear Stearns, with whom Franza became friendly. Bear Sterns agreed to capitalize Protein Databases, Inc., with \$1 million, which Franza said was quite a lot of money at the time, especially for a young, unproven company in a new field. However, Franza stressed the importance of Jim Watson's support for the new company it getting started. ${ }^{74}$

Biotechnology was gaining momentum on Long Island. In the early 1980s, three areas of the United States had cemented their reputations as important focal points of the industry: California, Massachusetts, and North Carolina. ${ }^{75}$ New York, especially Long Island, was becoming part of the conversation, however. Both New York State and Nassau County had approved millions of dollars' worth of grants and bond issues for technology development in the early part of the decade. ${ }^{76}$ The idea was simply to attract as much scientific entrepreneurship as possible. CSHL administrators were keenly aware of this new business activity going on around them. In March 1983, for instance, Watson informed the Executive Committee of a new company that was in the works that would focus on developing cancer therapies. ${ }^{77}$

\footnotetext{
${ }^{70}$ Ibid.

71 “A Company Discovered in the Lab,” Newsday, 8 October 1984, pp. 1,14 (Business Section), courtesy of Jim Garrels.

${ }^{72}$ Robert Franza, phone interview by Robert Wargas, 25 October 2012.

73 “Newsday, 8 October 1984.

${ }^{74}$ Robert Franza interview.

75 “NY in Pursuit of High-Tech,” Newsday, 11 July 1982.

${ }^{76}$ Ibid.; “Nassau IDA OKs Biology Lab's Bond,” Newsday, 19 October 1981.

${ }^{77}$ Executive Committee Meeting, 13 May 1983, CSHL Archives, Minutes 1983-1984.
} 
This company was to be called Oncogene Science, Inc. (later known as “OSI”), and it was to be spearheaded by Gary Takata and John Stephenson, the latter of whom had been a researcher at the National Cancer Institute. The company took its name from a popular research focus in molecular biology at the time: cancer-causing genes, known more colloquially as "oncogenes." Mike Wigler stood as an important figure in this area of research. In 1981, he and his team had isolated the first human oncogene from bladder cancer and were able to create cancer in a healthy mouse cell with the gene. Representatives of Oncogene Science approached Mitch Goldfarb, a scientist in Wigler's lab, about their idea to establish a company based on oncogene research. ${ }^{78}$ Wigler was offered a consultancy with the company. Watson also figured into the company's strategy; seeking the names of established scientists, the founders considered making him an administrator in the company, or at least offering him some kind of consultancy. ${ }^{79}$ Watson eventually decided against any kind of authoritative role in the company, becoming a member of the scientific advisory board instead. ${ }^{80}$

Oncogene Science's location was the subject of some dispute. The founders of the company had originally wanted it to be located in New Jersey, but Watson pushed for a spot closer to Cold Spring Harbor, and refused to get involved unless his demand was met. ${ }^{81}$ (The founders ostensibly relented; Oncogene Science ended up settling in Mineola.) Owing to the company's proximity to CSHL, Norton Zinder worried that Oncogene Science constituted a conflict of interest for the Lab, or at least gave the appearance of one. Sambrook, too, advised that the Lab not become too involved with the new company for the same reason. Watson responded by saying that he wanted to promote Long Island's biotechnology industry, and that having a company nearby would mean the possibility of consulting with its staff. ${ }^{82}$

In light of Watson's response, it is not surprising that Cold Spring Harbor continued to deepen its involvement in commercial science for the rest of the 1980s. By 1983, CSHL administrators had already "moved from the basic challenges of 'should we' to 'how do we best' handle such [commercial] relationships.” 83 That year, the Board of Trustees created a Commercial Relations Committee, whose purpose was to review all proposed arrangements between CSHL and the industrial world ${ }^{84}$ and to guard against conflicts of interest. The committee would benefit from the counsel and guidance of important Laboratory scientists, such as Rich Roberts and Bruce Stillman, both of whom continued to assume greater responsibilities. Roberts would become Assistant Director for Research in 1986, shortly after Sambrook’s departure for the University of Texas Southwest Medical Center. Stillman, who had come to the Lab in 1979 as a post-doctoral

\footnotetext{
${ }^{78}$ Mike Wigler, interview with Robert Wargas \& Mila Pollock, Cold Spring Harbor Laboratory, 22 March 2013.

${ }^{79}$ Executive Committee Meeting, 13 May 1983, CSHL Archives, Minutes 1983-1984.

${ }^{80}$ Executive Committee Meeting, 10 June 1983, ibid.

${ }^{81}$ John Maroney, interview by Robert Wargas, Cold Spring Harbor Laboratory, 28 September 2012.

${ }^{82}$ Executive Committee Meeting, 10 June 1983, CSHL Archives, Minutes 1983-1984.

${ }^{83}$ CSHL Annual Report 1983, 9.

${ }^{84}$ Executive Committee Meeting, 18 November 1983, CSHL Archives, Minutes 1983-1984.
} 
researcher, began solidifying a reputation as an effective leader in the 1980s. John Maroney recalls that though Stillman himself was not involved in biotechnology, he became a powerful voice on the Commercial Relations Committee. ${ }^{85}$ Stillman would become Assistant Director of the Laboratory in 1990 and succeed Watson as director in 1994.

In addition to the Exxon deal, the 1980s saw other lucrative corporate collaborations for CSHL. One was a research-support relationship with Amersham, a British pharmaceutical company, to support Ed Harlow's work at CSHL in monoclonal antibodies. ${ }^{86}$ Another major deal was a fiveyear, \$2.1 million agreement with Monsanto to study mouse genetics, specifically gene transfer and gene expression in mammalian development. ${ }^{87}$ This was followed by a five-year, $\$ 2.5$ million deal with Pioneer Hi-Bred International, signed in August 1985. This latter deal concerned Pioneer's supporting CSHL's research in the use of recombinant DNA techniques on maize, with the agreement that Pioneer would get the license on whatever technology came out of the program.

Cold Spring Harbor Laboratory had not yet done much by way of patenting. The institution's first patent had been granted in 1977, for Bruce Detroy’s two-dimensional gel boxes. ${ }^{88}$ It was Mike Wigler, however, who would bring CSHL its first taste of significant patent royalties. Before coming to CSHL, Wigler had completed his doctorate at Columbia University, working with Richard Axel. There, along with Saul Silverstein, they had developed important methods known as cotransformation and coamplification. These were essentially eukaryotic analogues of recombinant DNA, a method restricted to prokaryotes. One study put it succinctly: "the process [cotransformation] allowed the incorporation of any known gene, prokaryotic or eukaryotic, into any mammalian cell.” The more colloquial term for the technology is "the Wigler Method," since the whole idea is generally recognized as Wigler's. ${ }^{89}$ The method's novelty involves inserting two genes into a cell. The first codes for a desirable protein product, the second for a substance (i.e. a marker) that will help to identify those cells that have acquired the inserted genes. For instance, in addition to a gene coding for the desired product, a gene for a substance resistant to a particular toxin may also be introduced. Afterwards, the treated cells are exposed to

\footnotetext{
${ }^{85}$ John Maroney, interview with Robert Wargas \& Mila Pollock, Cold Spring Harbor Laboratory, 27 June 2013.

${ }^{86}$ CSHL Archives, Office of Technology Transfer files, boxes 3 and 4.

${ }^{87}$ Annual Report 1984, 7.

${ }^{88}$ Jim Hicks et. al. interview, 11 January 2013; confirmed by PTO online database records.

${ }^{89}$ C. Alessandra Colaianni, “The Axel Patents: A Case Study in University Technology Transfer," unpublished report supported by the Center for Public Genomics of Duke University, 26 September 2007, 3-4. For a similar, published study, see C. Alessandra Colaianni and Robert M. Cook-Deegan, "Columbia University's Axel Patents: Technology Transfer and Implications for the Bayh-Dole Act,” Milbank Quarterly 87, issue 3, September 2009, 683-715.
} 
that toxin. Only the cells that have successfully incorporated the foreign DNA into its genome will survive. ${ }^{90}$

A patent for the method was filed on February 25, $1980 .{ }^{91}$ In an interview on the topic, Wigler said it was Axel who had suggested patenting cotransformation, which, to Wigler, was "a rather odd thing to do" at the time-a good reminder that patenting was not on many scientists' minds during that era of science. ${ }^{92}$ Though important parts of the cotransformation experiments had been done by Wigler while at CSHL-he began working there in 1978 — the Lab did not begin receiving royalties on the patents until much later. In the mid-1980s, Wigler mentioned to Jim Watson that CSHL could secure some of the royalties. It would take several more years until John Maroney could negotiate a deal with Columbia for five percent of the patent revenues. ${ }^{93}$ According to William Keen, who was CSHL's comptroller from 1971 to 2011, this deal would bring the Laboratory at least $\$ 1$ million a year over ten years. ${ }^{94}$

\section{Preparing for the Second Century}

The increased involvement with biotechnology in the 1980s meant the need to expand the Laboratory itself. There had been talk at CSHL at least as early as 1984 about instituting a major capital fundraising program, the impetus for which was the realization that the Lab had no comprehensive fundraising strategy in place. In November 1984, for instance, the Board of Trustees noted: "Past fundraising has been a reflexive, knee-jerk response to pressures for expansion. We have been so perpetually involved in present crises that we never had enough time to plan comprehensively for the future."95

The Lab’s administrators envisioned a continuous fundraising program based on sponsorship from corporations and charities. Similar proposals had been made in the past, but none had been implemented. ${ }^{96}$ What came out of this idea would become known as the Second Century campaign, so named because 1990 would mark CSHL's $100^{\text {th }}$ anniversary. The goal of the campaign was to keep CSHL in its place as a leader in the biological sciences by ensuring that the Lab's plant and equipment were up to date. It also meant making sure the Lab took chances

\footnotetext{
${ }^{90}$ Trustees of Columbia Univ. v. Roche Diagnostics GMBH, 126 F.Supp.2d 16 (2000), No. 93-11512-

NG, United States District Court, D. Massachusetts, 11 December 2000.

${ }^{91}$ Colaianni, “The Axel Patents: A Case Study in University Technology Transfer,” 3.

${ }^{92}$ Ibid., 8.

${ }^{93}$ John Maroney, interview by Robert Wargas, Cold Spring Harbor Laboratory, 3 July 2012; Morgan

Browne, Jim Hicks, Bill Keen, John Maroney, interview by Robert Wargas \& Mila Pollock, Cold Spring Harbor Laboratory, 11 January 2013.

${ }^{94}$ Bill Keen, interview by Robert Wargas, Cold Spring Harbor Laboratory, 6 August 2012.

95 “A Preliminary Plan for a Second Century Campaign, 1985-1990,” Board of Trustees Meeting, 10 November 1984, Zinder Collection, box 129.

${ }^{96}$ Retrospectus 1983, Zinder Collection, box 129; Morgan Browne, interview by Robert Wargas, Cold Spring Harbor Laboratory, 27 June 2012.
} 
on up-and-coming areas of science. Toward this end, a centerpiece of the program was a plan to build a large neuroscience center on Laboratory grounds. CSHL had been involved in teaching and researching neurobiology since $1974,{ }^{97}$ mostly in annual summer courses, but it had not yet integrated the study of the brain into its full-time research focus. At least as early as 1983, CSHL administrators wondered whether the Laboratory needed a new building to house a year-round neurobiology program. ${ }^{98}$

The biological sciences had grown significantly since Watson and Crick's discovery of the double helix. They had grown even more so since genetic engineering had become a reality the previous decade. By 1983, molecular biology had created synthetic human insulin, made more connections between genes and cancer, and important discoveries had been made concerning the AIDS virus. In this last endeavor, CSHL had played its own important role, hosting an important conference of AIDS researchers in September 1983 at which Luc Montagnier first publicly announced the discovery of the virus. ${ }^{99}$

Neuroscience remained a relatively barren frontier. Unraveling the mysteries of the brain was as fresh as research on tumor viruses had been fifteen years earlier. It was the area of science to which Francis Crick had turned after molecular genetics, and it held promise in both basic science and biotechnology. According to Morgan Browne, who was Cold Spring Harbor Laboratory's Administrative Director from 1985 to 2000, the neuroscience center was entirely Watson's idea. ${ }^{100}$ Since it would constitute the largest expansion of the Laboratory in its history up until that time, the idea was not without its detractors, who thought Cold Spring Harbor might become too big for its own good. ${ }^{101}$

But the Lab’s administrators were not just concerned with building for building's sake. With the commercial science industry growing, Cold Spring Harbor needed to become a more attractive place for young scientists to work. ${ }^{102}$ This stemmed from the worry that private industry was becoming more lucrative for molecular biologists in general, and that it might continue to attract talent away from universities and non-profit research institutions. Cold Spring Harbor itself suffered from its reputation as a place at which traditional tenure appointments were not offered.

\footnotetext{
${ }^{97}$ CSHL Annual Report 1980, 9.

${ }^{98}$ Infrastructure \& Future Planning Committee document, circa 1983, Zinder Collection, box 131.

99 "CSH Lab to Conduct AIDS Research,” The Long-Islander, 29 September 1988; "With Etiologic Clues Sparse, Search Is On,” Medical News, 4 April 1983; “Hope Dims for AIDS Vaccine,” Newsday, 14 September 1986. All related news articles are collected in the CSHL Archives. See also montagnier.org/Scientific-findings for timeline on AIDS discoveries and their announcement at the CSHL meeting in 1983.

${ }^{100}$ Morgan Browne interview, 27 June 2012.

${ }^{101}$ William Keen interview, 6 August 2012.

${ }^{102}$ Retrospectus 1983, Zinder Collection, box 129.
} 
The closest thing to such a tenured position was the Laboratory's "rolling five" appointment, in which a scientist was granted continuous five-year research- and salary-support commitments. ${ }^{103}$

The financial goals of the Second Century campaign included raising \$44 million for capital projects. Despite Cold Spring Harbor's prominence, the Second Century Campaign was unprecedented in the scope of its goals. Watson's financing strategy was to approach "the major international pharmaceutical and biotechnological corporations who benefit from the Lab's existence" in order to secure funding. ${ }^{104}$

With the proposed neuroscience center as its centerpiece, CSHL sought major donations from major organizations. In this it was undoubtedly successful. In October 1987, for instance, it was announced that the Laboratory had received \$7 million from the Howard Hughes Medical Institute, $\$ 5$ million of which would be put toward construction of the neuroscience center. It was at the time the largest foundation grant the Laboratory had ever received. ${ }^{105}$ In December, the chemist and philanthropist Arnold Beckman, founder of the Arnold and Mabel Beckman Foundation, told Watson that, thanks to Black Monday, the weakened economy made donations difficult. Nevertheless, Watson persisted. In February 1988, it was announced that Beckman had decided to contribute $\$ 4$ million toward the project. The legacy of this contribution is the naming of the neuroscience laboratory after Beckman and his wife. ${ }^{106}$

By July 1988, the Lab had raised \$15 million for the neuroscience center through Beckman and other foundations. Nevertheless, Watson wrote at the time that he viewed funding for the project as "the real complication of my existence." At the time, the center was projected to cost $\$ 20$ million, and there was still significant funding that needed to be secured. That month brought good news, however, when the Dolan Family Foundation-Helen Dolan was a CSHL trustee at the time-announced that they would provide $\$ 2$ million toward the residence hall component of the project. ${ }^{107}$

Despite the success of the fundraising campaign, CSHL had to watch as another potential source of revenue slipped away. An international dispute had developed over who had the right to market the recombinant form of TPA, which CSHL had worked on earlier in the decade. Genentech had filed lawsuits all over the world against companies they alleged were infringing on their patents. One such lawsuit was against the Wellcome Foundation, to which Baxter Travenol had sold its interests in TPA. In July 1987, Genentech lost its case against Wellcome

\footnotetext{
${ }^{103}$ CSHL Annual Report, 1978, 18; CSHL Annual Report 1980, 15.

104 James Watson to Fritz Melchers, 16 January 1990, Watson Collection, 3/7/3, box 3.

105 “Record Grant for Cold Spring Lab,” Newsday, 8 October 1987.

${ }^{106}$ James Watson to Rebecca W. Rimel, 24 February 1988, Watson Collection, 3/7/3, box 15; Executive Committee Meeting, 12 March 1988, Minutes, 1987-1988.

107 James Watson to Bernhard Hirt, 16 July 1988, Watson Collection, series III, box 3; James Watson to Robert J. Glaser, 16 July 1988, ibid.
} 
when the London High Court of Justice rules that its British patent was too broad; Wellcome had defended itself by arguing against the “obviousness” of Genentech's cloning technique. ${ }^{108}$

In November, the U.S. Food and Drug Administration announced it would approve TPA after a long dispute over the drug's safety. ${ }^{109}$ The following year, in June 1988, the New York Times reported that Genentech "had received a broad patent for purified” TPA. ${ }^{110}$ The legal complexities involved with patenting TPA included the fact that, as the Times put it, "TPA is a naturally occurring human protein that can be imitated in scores of slightly different ways." 111 Though Genentech had lost its British patent, it continued to fight to maintain its market share in the United States, even as other companies, such as Biogen and Monsanto, had received patents for their own versions of TPA. ${ }^{112}$ Genentech's version, which the company called “Activase," was expected to bring in as much as $\$ 200$ million in sales revenue that year alone. ${ }^{113}$ In fact, only five months after getting FDA approval to market TPA, the company had already seen \$100 million in sales. ${ }^{114}$ A U.S. District Court ruled finally ruled in April 1990 that all of Genentech's American patents on TPA were valid, effectively barring Burroughs Wellcome and Genetics Institute from selling the drug. ${ }^{115}$ Nevertheless, TPA's reputation had already been dealt a blow the previous year, in March 1989, when a study in The New England Journal of Medicine concluded that there was no difference in effectiveness between TPA and streptokinase, a much cheaper drug. ${ }^{116}$ This study eventually damaged Genentech’s TPA sales significantly. ${ }^{117}$

By the end of the 1980s, James Watson's responsibilities had expanded beyond Cold Spring Harbor. The concept of sequencing the entire human genome had been transformed from a somewhat fanciful idea into an actual project under the purview of the United States government. What would become known as the Human Genome Project fell under the auspices of the National Institutes of Health, and in April 1988 Watson had been asked by James Wyngaarden, then head of the NIH, to serve as associate director of the project. ${ }^{118}$ Watson would divide his time between Cold Spring Harbor and Washington, D.C. He was enthusiastic about the offer, as were the Lab's trustees, who unanimously voted to support his signing on to the project. ${ }^{119}$ In the

108 “Genentech Loses Patent,” New York Times, 8 July 1987.

109 “U.S. to Back Gene-Engineered Drug for Clotting,” New York Times, 13 November 1987.

110 “Genentech Gets Patent for Drug for Blood Clots,” New York Times, 22 June 1988.

111 “The Complex Legal Issues in TPA Fight,” New York Times, 2 July 1988.

${ }^{112}$ Ibid.

${ }^{113}$ Ibid.

${ }^{114}$ New York Times, 2 July 1988.

115 “Jury Supports Genentech in Patent Infringement Case,” New York Times, 7 April 1990.

116 “Study Finds No Difference in 2 Heart Attack Drugs,” New York Times, 30 March 1989; Harvey D. White, et. al., "Effect of Intravenous Streptokinase as Compared with That of Tissue Plasminogen Activator on Left Ventricular Function after First Myocardial Infarction,” New England Journal of Medicine 320, no. 13 (30 March 1989): 817-821.

117 “Genentech Says TPA’s Market Share Falls,” New York Times, 18 July 1991.

${ }^{118}$ Executive Committee Meeting, 16 April 1988, Minutes, 1987-1988, 92.

${ }^{119}$ Board of Trustees Meeting, 7 May 1988, Minutes 1987-1988. 
midst of the large fundraising drive, Watson shrewdly made clear to Wyngaarden that his acceptance of the NIH position would be contingent on whether he received more funding for the Neuroscience Center. Wyngaarden responded by urging large foundations to support the center. ${ }^{120}$ To Watson, expanding CSHL was an inevitable response to the larger forces at work in the world of science. In October 1989, James Watson wrote to a correspondent, "We have no choice but to upgrade ourselves for the biotechnology world of the next century..." ${ }^{121}$ The 1980s had been a time of revolutionary change for CSHL, and the transition to both a new decade and a new century was complete.

\section{Beyond the Second Century: 1990-present}

Cold Spring Harbor Laboratory’s second century began in 1990 with the celebration of its centennial. Biotechnology had become established as part of CSHL's culture, and though it had lost some of its early luster and novelty, involvement in it did not slow down. The 1990s was, for CSHL scientists, the decade of increased involvement with start-up companies. One of the most notable of such start-ups was a company called ICOS, which was established in 1990. The founders of ICOS had previously established themselves as successful and influential figures in biotechnology. George Rathmann had founded Amgen, a renowned company, a decade earlier; Robert Nowinski had founded Genetic Systems Corporation, and Christopher Henney had founded Immunex, a major biotech player in Seattle, where ICOS was based. These entrepreneurs, relying on their name recognition, bypassed venture-capital companies and were able to secure \$33 million from private individuals, including Bill Gates, in order to fund the start-up of ICOS. ${ }^{122}$ Though originally formed to focus on inflammatory diseases, ICOS quickly moved in the direction of developing Mike Wigler's research, completed at CSHL, on phosphodiesterases (PDEs). ${ }^{123}$

The ICOS founders sought two things. First, they wanted other reputable names in science associated with their company. To this end, they asked James Watson to be on the company's scientific advisory board. They also sought technology to develop, and for this they approached Mike Wigler, who had just ended a consultancy with Pfizer. ${ }^{124}$ Wigler's PDE technology, then, formed the basis for ICOS's early development, and CSHL was given founder's stock in the company. ICOS would go on to become an important manufacturer of the popular drug Cialis.

\footnotetext{
${ }^{120}$ Executive Committee Meeting, 10 June 1988, ibid., 104.

${ }^{121}$ James Watson to John A. Luke, 18 October 1989, Watson Collection, 3/7/3, box 3.

${ }^{122}$ Seattle Post Intelligencer, July 1990, quoted in John Cook, “The early days at ICOS,” Seattle PI blog, 17 October 2006, accessed 7 June 2012.

${ }^{123}$ ICOS Corporation memo, 9 April 1990, CSHL Archives, Office of Technology Transfer files; Mike Wigler, interview by Robert Wargas \& Mila Pollock, Cold Spring Harbor Laboratory, 22 March 2013.

${ }^{124}$ Ibid.; Jim Hicks et. al. interview, 11 January 2013; Rich Roberts interview, 12 April 2013.
} 
CSHL ended up getting \$3 million from the sale of its stock. ${ }^{125}$ The company was eventually sold to Eli Lilly in 2007.

Wigler, who by his own admission hadn't been interested in biotech in the 1980s, ${ }^{126}$ became a notable entrepreneur after his involvement with ICOS. He was one of several CSHL scientists who would increase his involvement with biotechnology in the 1990s by establishing several start-up companies. These were generally small biotech ventures based on single, specific technologies. Wigler started PathoGenesis in 1991 to develop drugs to treat bacterial, viral, and fungal infections. The particular targets were serious diseases requiring long-term therapy, such as tuberculosis and infections arising from cystic fibrosis. ${ }^{127}$ In March 1993, the company signed a license agreement with CSHL to use a Laboratory-patented method of representational genomic analysis in the study of infectious diseases. ${ }^{128}$

In a 2013 interview, however, Wigler called PathoGenesis a "wasted opportunity”: though it was a company based on solid technology, nothing was developed properly. ${ }^{129}$ Moreover, a legal dispute in 1994 between Wigler and PathoGenesis, in which Wigler was wrongfully accused of stealing intellectual property, "severely damaged” his relationship with the company. ${ }^{130}$ PathoGenesis was acquired by the Chiron Corporation in 2000 for $\$ 700$ million. ${ }^{131}$

Wigler continued to translate his scientific discoveries into business opportunities. In 1993, he and Clark Still of Columbia University formed Pharmacopeia, a company that would use combinatorial chemical libraries for drug discovery. Based in Princeton, New Jersey, the company was the first to make use of combinatorial chemistry, this novelty, Wigler has said, was what made Pharmacopeia successful. Nevertheless, he still felt that Pharmacopeia, like PathoGenesis, had potential that was not developed. ${ }^{132}$ Still another Wigler company, Amplicon, was based on his work with Nicholai Lisitsyn in representational difference analysis, a method for detecting differences in genomes. Created in 1994 with the help of the Long Island Venture Fund, Amplicon sought to identify parts of the human genome that could indicate a predisposition to cancer. ${ }^{133}$

\footnotetext{
${ }^{125}$ John Maroney, email to Robert Wargas, 11 January 2013.

${ }^{126}$ Mike Wigler interview, 22 March 2013.

${ }^{127}$ Business Description, undated, Nichols files, box “OTT Storage.”

${ }^{128}$ License Agreement, 11 March 1993, Nichols files, box "Dormant Safe Files.”

${ }^{129}$ Mike Wigler interview.

${ }^{130}$ Ibid.; John Maroney to Bill Gantz, 14 September 1994, Nichols files, box “OTT Storage”; Michael Wigler to Robert Nowinski, 12 September 1994, ibid.

131 "Chiron to Acquire PathoGenesis for \$700 Million,” New York Times, 15 August 2000.

${ }^{132}$ Mike Wigler interview.

${ }^{133}$ Statement of the Sole Incorporator, 15 November 1994, Nichols files, box “Tularik”; Michael Unger, “Discovery Zones,” Newsday, 16 October 1995; Board of Trustees Meeting, 5 November 1994, Minutes 1993-1994, 6.
} 
Wigler and Lisitsyn devised a method in which a section of DNA from an unhealthy tissue is amplified using polymerase chain reaction (PCR) and marked on both helical strands. The marked DNA is then mixed with pieces of healthy, unmarked DNA. The solution is heated to the point where the DNA helices begin to “unzip.” When cooled, all the single strands begin "searching" for identical strands to zip themselves back up. The normal strands are able to find partners, while the abnormal ones - the ones the investigator is trying to identify - cannot match with any others. Consequently, the unhealthy pieces of DNA end up partnering with one another. These abnormal sequences are identified by the presence of the two chemical markers used before the process was begun. ${ }^{134}$

RDA proved immensely useful. It helped Yuan Chang and Patrick Moore, two researchers at Columbia University, to identify a virus they believed caused Kaposi's sarcoma in AIDS patients, ${ }^{135}$ and researchers at Abbott Laboratories also used the method to identify three unknown hepatitis viruses. In addition, Wigler's other company, PathoGenesis, used RDA “to identify a form of human herpesvirus that may be associated with multiple sclerosis.”136

Other CSHL scientists who would start companies included David Beach, who had come to CSHL in 1982. He would make a name for himself as one of the Laboratory's most enterprising scientists. In 1985, Beach made important discoveries in yeast genetics and produced a string of highly regarded and frequently cited papers on the biochemistry of cell division. Along with young scientists like Giulio Draetta, Leonardo Brizuela, and Robert N. Booher, Beach clarified the molecular pathways that controlled cell division in yeast. ${ }^{137}$

Beach established a company called Mitotix in 1992, after a group of investors had approached him about the possibility of a start-up venture based on the cell cycle. ${ }^{138}$ An office was opened in Cambridge, Massachusetts. The establishment of such a company was fortuitous: In late 1993, Beach made several breakthroughs in the study of cancer genetics that would form the basis of work in Mitotix. One breakthrough was the discovery that the p21 protein was missing [?] in cancer cells and was regulated by a critical cell-division and tumor-suppressor gene called p53. Beach and his team found that genetic damage could lead to a buildup of the protein produced by p53; this activates the p21 gene, whose protein puts the brakes on cell division. Beach's team included Yue Xlong, Greg Hannon, Hui Zhang, David Casso, Manuel Serrano, and Ryuji Kobayashi. "Now," Beach said at the time, explaining the significance of the findings, "we think we've found the connecting link between the p53 gene and the inhibition of tumor growth.”"139

\footnotetext{
134 “Trapping Genetic Killers,” Newsday, 9 May 1995, B25.

135 “Going Off the Beaten Path to Track Down Clues About AIDS,” New York Times, 20 December 1994.

${ }^{136}$ CSHL Annual Report 1995, 15.

137 “Cold Spring Harbor Team: Setting Sail for New Waters,” The Scientist, 5 March 1990, CSHL Archives.

${ }^{138}$ Board of Trustees Meeting, 22 February 1992, Minutes 1991-1992.

${ }^{139}$ Executive Committee Meeting, 17 December 1993, Minutes 1993-1994, CSHL Archives; “CancerControl Proteins IDd,” Newsday, 16 December 1993.
} 
The p53 gene, discovered in 1979, had already been implicated in tumorigenesis. In 1989, Dr. Bert Vogelstein and other researchers at Johns Hopkins University had identified p53 in the development of colorectal cancer. ${ }^{140}$ Vogelstein's work was praised at that the 1989 CSHL Symposium. ${ }^{141}$

Beach published his findings on p21 in Nature, in the December 16, 1993, issue. ${ }^{142}$ In a separate article in the same issue, ${ }^{143}$ he announced that the p16 gene inhibits certain enzymes (cyclindependent kinases, or CDKs) that are directly involved in cell division. ${ }^{144}$ Beach thus suspected that p16 played a role in tumor suppression owing to its function as a cell-growth regulator. Interestingly, at the same time, Alexander Kamb and Mark Skolnick, researchers at the University of Utah and Myriad Genetics, were working on the same gene-but for different reasons, and each group was unaware of the other's work. Kamb and Skolnick had found that p16 (which they referred to as MTS1, for “multiple tumor suppressor 1") was either missing from, or present in mutated form in, nearly half of 290 tumor samples they had been studying over a long time period. They also found that p16/MTS1 is never mutated in or missing from non-cancerous cells. ${ }^{145}$

These discoveries were an interesting and unexpected confluence of research between two separate groups. There immediately arose a conflict, however, since both CSHL and the University of Utah had filed patents for p16 and MTS1, respectively, and had granted licenses to those patents to Mitotix and Myriad. Since p16 and MTS1 referred to the same gene, the U.S. Patent and Trademark Office declared interference in the patent filings. ${ }^{146}$ According to Beach, the patent case was resolved largely in favor of Mitotix, though the company was eventually sold to GPC Biotech, a German company. ${ }^{147}$

\footnotetext{
${ }^{140}$ Bert Vogelstein, et. al., "Chromosome 17 deletions and p53 gene mutations in colorectal carcinomas," Science 244 (14 April 1989): 217-221; "Mutations in the p53 gene occur in diverse human tumour types," Nature 342 (7 December 1989): 705-708.

141 “Study says gene may help detect colon cancer early,” The Virginian-Pilot, 16 April 1989, CSHL Archives.

${ }^{142}$ Yue Xiong, Gregory J. Hannon, Hui Zhang, David Casso, Ryuji Kobayashi \& David Beach, "p21 is a universal inhibitor of cyclin kinases,” Nature 366 (16 December 1993): 701-704.

${ }^{143}$ Manual Serrano, Gregory J. Hannon \& David Beach, “A new regulatory motif in cell-cycle control causing specific inhibition of cyclin D/CDK4,” Nature 366 (16 December 1993): 704-707.

${ }^{144}$ Newsday, 16 December 1993.

145 “One Gene Triggers Many Kinds of Cancer, Utah Scientists Find,” Wall Street Journal, 14 April 1994, B1-B2.

${ }^{146}$ Nichols files, box “Administration Mitotix P-16.”

${ }^{147}$ David Beach, e-mail to Mila Pollock, 22 June 2013.
} 


\section{CSHL and the Expansion of Long Island Biotechnology}

James Watson stepped down as CSHL's director in January 1994, passing the torch to Bruce Stillman, who had proven himself as an effective administrator after becoming assistant director in 1990. Watson, meanwhile, assumed the newly created position of president, which allowed him to continue serving CSHL, especially in fundraising. Stillman assumed the directorship at a remarkably young age, having established himself as an important researcher in DNA replication, a role he resumed even after undertaking to manage the day-to-day business of the Laboratory. Under Stillman's watch, CSHL would continue to assert itself as a force in biotechnology, and, moreover, the Lab would work even harder to make the industry a prominent part of the Long Island economy. Because of the increasing presence of biotech companies in the area, and the trend among individual scientists to consult and create their own companies, one of Stillman's first moves as director was to focus the Laboratory's vigilance on possible conflicts of interests - a common concern in the previous decade. He instructed the Board of Trustees, for instance, that no CSHL scientist should be allowed to serve as the director of a biotech company. ${ }^{148}$

As start-up companies became more common on Long Island, the opportunities for academic science to interact with business enhanced the region's reputation as a center of American biotechnology. This was doubtless due to the presence of major scientific research centers in the surrounding area-not just Cold Spring Harbor and SUNY Stony Brook, but also Columbia and Rockefeller universities as well as the Albert Einstein College of Medicine. The expansion of biotechnology on Long Island coincided with the downturn in the defense industry that occurred after the end of the Cold War. Grumman, the defense and aerospace giant that provided the island with thousands of jobs, was forced to downsize drastically. The economic vacuum created an opportunity for other high technology business, ${ }^{149}$ and the universities on and near Long Island, with the help of the New York State government, began to expand biotechnology. In 1992, for instance, the Long Island High Technology Incubator opened in Stony Brook. ${ }^{150}$

The "incubator" model would prove popular in the biotech industry in general and on Long Island in particular. Incubators are clusters of biotech businesses located near major academic research centers. Since new biotech companies take some time to become independent, let alone successful, it helps to have the guidance and support of established nearby companies. The incubators provide reasonably priced space as well as proximity to other companies and resources to help nurture the new companies. The concept has grown significantly over the past

\footnotetext{
${ }^{148}$ Bruce Stillman, interview with Robert Wargas \& Mila Pollock, Cold Spring Harbor Laboratory, 13 November 2012.

${ }^{149}$ See, for example, “'110 Corridor’ Gets State Funding Boost,” Long Island Business News, 16 March 1998.

150 “State Plans 'Incubators’ To Breed New Businesses,” Newsday, 28 February 1996.
} 
few decades and is especially common in the high-technology fields. ${ }^{151}$ Under that model, biotechnology has grown considerably in New York. By February 1996, for example, the biotech incubator at Stony Brook contained 29 companies, with 25 others occupying spare space. ${ }^{152}$

Biotech on Long Island has always been a public-private enterprise. Though led from below by entrepreneurial scientists and venture capitalists, the industry has benefited from enormous subsidies and assistance on the part of New York State. In 1996, the state created the Long Island Regional Incubator Task Force, a body charged with recommending measures to help Long Island's emerging applied-science sector. ${ }^{153}$ In September of that year, SUNY Stony Brook broke ground on what was to become the Centers for Molecular Medicine and Biology Learning Laboratories on their campus. ${ }^{154} \mathrm{CSHL}$, being one of the premier biological research institutions in the country, became central to this public-private revival of Long Island's industry. Its main contribution was what became known as Broad Hollow Bioscience Park. In June 1997, SUNY Farmingdale announced that it, along with Cold Spring Harbor Laboratory, was proposing a biotechnology park on a 20-acre parcel of campus land. The SUNY Board of Trustees had already endorsed the proposal. ${ }^{155}$

In April 1998, the president of SUNY Farmingdale announced that more than \$14 million had been awarded to both Farmingdale and CSHL to build the biotech park. This was part of a larger New York State plan, which Pataki had announced the previous month, to put \$22 million into six incubators on Long Island in the biotech, software, and emerging technologies fields. ${ }^{156}$ These new centers were the SUNY/CSHL Biotech Park, the North Shore University Hospital Biotech Incubator, the Briarcliffe College Software Incubator, the SUNY Stony Brook software incubator, the SUNY Farmingdale Manufacturing Incubator, and the Suffolk Community College Emerging Technologies Incubator. ${ }^{157}$

As of early 1998, 33 percent of the biotech companies in New York State were located on Long Island, with Cold Spring Harbor having a sizable share of the market. Up until that time, as Morgan Browne told reporters, "the technology and know-how of Cold Spring Harbor Laboratory scientists have already led to the formation of 13 biotechnology companies with a

\footnotetext{
${ }^{151}$ See, for example, National Business Incubation Association, "New Study Shows Business Incubation Has Significant Economic Impact,” press release, November 1997, Nichols files, box "Bio Park John.” ${ }^{152}$ Newsday, 28 February 1996.

153 “Governor, Legislators Unveil High-Tech Incubators on Long Island,” press release, 5 March 1998, Nichols files, box "Bio Park John."

154 "Focus at Lab Groundbreaking is Biotech Research and Jobs," New York Times, 4 September 1996.

155 “SUNY Farmingdale and Cold Spring Harbor,” Farmingdale State University news release, 19 June 1997, Nichols files, box "Bio Park John."

156 “Biotechnology Park Announced,” Farmingdale State University press release, 7 April 1998, ibid.

157 “Governor, Legislators Unveil High-Tech Incubators on Long Island,” press release, 5 March 1998, Nichols Building files, box “Bio Park John.”
} 
collective market capitalization of more than $\$ 1$ billion.” ${ }^{158}$ In October of that year, ground was broken for Broad Hollow Bioscience Park at SUNY Farmingdale. Part of the intention of this park was to "halt the exodus of biotech startups nurtured at nearby Cold Spring Harbor Laboratory." 159 Clusters of biotech companies, as well as university-affiliated biotech projects, were becoming increasingly common. The next year, in November 1999, the Centers for Molecular Medicine, begun in 1996, had its grand opening at SUNY Stony Brook.

Meanwhile, CSHL scientists had continued to make names for themselves in their own business pursuits, which were based on breakthroughs they had made in their labs. Tim Tully, a neurogeneticist who had come to the Laboratory in 1991, established a company called Helicon Therapeutics. Founded in 1997 as a joint venture between CSHL, Oncogene Science, and the Hoffman LaRoche pharmaceutical company, Helicon's focus was drug discovery for memoryrelated illness. ${ }^{160}$ Tully had made a name for himself for his discoveries, with fellow CSHL scientists Alcino Silva and Jerry Yin, relating to the effect of the CREB gene on short-term memory.

It was during the latter part of the 1990s that Cold Spring Harbor decided to expand once again, this time realizing a long-held plan to turn the Laboratory into a legitimate, degree-granting university. This officially happened on September 18, 1998, the result of almost three years of work by Laboratory administrators. ${ }^{161}$ Though CSHL had always taken part in educating graduating students, it never conferred its own degrees. (The desire to form a university goes back at least to 1989, when James Watson pitched The Lefrak Organization on a \$30 million gift for CSHL to become "the Caltech of Long Island."162) Eventually named the Watson School of Biological Sciences, the program took its first class in September 1999, offering admission to only nine students out of the one-hundred-thirty who had applied. Six students accepted. ${ }^{163}$

One year later, in September 2000, Broad Hollow Bioscience Park celebrated its grand opening. The park stood as the latest concrete example of the symbiotic relationship between the state and private sector. In fact, it is difficult to overstate just how important New York's state government was, and continues to be, toward growing the biotech sector. For Cold Spring Harbor, this state assistance has been particularly rewarding. On September 24, 2002, then-New York Governor George Pataki announced at CSHL that the state would put another \$20 million worth of investment into the Laboratory as part of a larger project to create a "biotechnology corridor" on

\footnotetext{
158 “LI’s Bioscience Boom,” Long Island Business News, 9 February 1998; “'110 Corridor’ Gets State Funding Boost,” Long Island Business News, 16 March 1998.

159 "Stemming the biotech goodbye tide,” Long Island Business News, 31 August 1998; "Groundbreaking Set for Biotech Park,” Newsday, 16 September 1998.

${ }^{160}$ For information on Helicon, see Nichols files, box “Helicon Board Materials,” among others.

${ }^{161}$ Annual Report 1998, 184.

162 James Watson to Samuel LeFrak, 29 September 1989, Watson Collection, 3/7/3, box 3.

${ }^{163}$ CSHL Annual Report 1999, 173.
} 
Long Island. ${ }^{164}$ This would eventually take the form of a bioinformatics center on the Laboratory campus, construction for which began in July 2005. ${ }^{165}$ In keeping with CSHL's history of receiving generous donations for private entities, in April 2006 Genentech announced it would give CSHL \$2.5 million to establish the Genentech Center for the History of Molecular Biology and Biotechnology. Located today in the expanded Carnegie Library Building, the center contains important historical materials, such as archival collections of important figures like James Watson and Sydney Brenner. ${ }^{166}$

Since the completion of the Human Genome Project in 2003, the fields of molecular biology and biotechnology have continued to interact in the hopes of advancing medicine. Genomics has become essential to forging new paths in medicine, especially in the field of cancer therapeutics. Under Stillman's leadership, Cold Spring Harbor Laboratory remained integral to this discipline within the biological sciences, opening its own Genome Center in Woodbury, New York, separate from its main campus — “a seed that I hope will lead to Nobel Prizes,” in Stillman's words. ${ }^{167}$ Along with ten other collaborators, the Laboratory also helped establish the New York Genome Center, which shares and integrates research and resources among New York's major biomedical research centers. ${ }^{168}$

The future of CSHL's involvement in biotechnology will depend simply on whether the Laboratory chooses to pursue promising ideas, not simply for the sake of starting companies. "We'll do it on a case-by-case basis," Stillman said in late 2012. ${ }^{169}$ Whatever the future may bring, it is clear that the past was a successful one: According to an official Lab publication, from 1987 to 2005, “CSHL generated more than \$110 million from technology licensing, startup companies, sponsored research, and other commercial activities.” ${ }^{170}$ But there can be no quantifying the change that CSHL has undergone since the biotech revolution began. "I think it was a great success," James Watson said in 2013. ${ }^{171}$ The transition was not an easy one, but the benefits of money, exposure, expansion and innovation were undeniable, as well as essential to carrying Cold Spring Harbor Laboratory into the twenty-first century.

\footnotetext{
${ }^{164}$ CSHL Annual Report 2002, 10.

165 "Nassau County Senate Delegation Breaks Ground for Biotechnology at CSHL," CSHL press release, 14 July 2005.

166 “Genentech Donates \$2.5 Million to Cold Spring Harbor Laboratory,” CSHL press release, 5 April 2006.

167 "Spitzer discusses how to boost LI tech sector,” Newsday, 12 January 2008.

168 "Big Genomics Center to Launch in Big Apple,” GenomeWeb Daily News, 3 November 2011; see also http://www.nygenome.org/about-us/about-us.

${ }^{169}$ Bruce Stillman interview, 13 November 2012.

${ }^{170}$ Harbor Transcript, Fall 2006, Vol. 26, No. 4, 4.

${ }^{171}$ James Watson, interview by Robert Wargas \& Mila Pollock, Cold Spring Harbor Laboratory, 13 May 2013.
} 